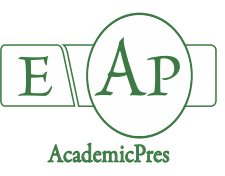

Akter S et al. (2020)

Notulae Botanicae Horti Agrobotanici Cluj-Napoca 48(3):1276-1291

DOI: $10.15835 /$ nbha48311676

Research Article

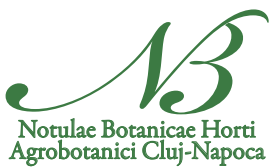

\title{
Expression of thaumatin, a new type of alternative sweetener in rice
}

\author{
Shahina AKTER ${ }^{1,2 a}, \mathrm{Md}$. Amdadul HUQ ${ }^{3 \mathrm{~b}}, \mathrm{Yu}-\mathrm{Jin}_{\mathrm{JUNG}}{ }^{1,4 *}$, \\ Kwon-Kyoo KANG ${ }^{1,4 *}$
}

\author{
${ }^{1}$ Hankyong National University, Department of Horticultural Life Science, Anseong 17579, \\ Republic of Korea; shahinabristy16@gmail.com; yuyu1216@hknu.ac.kr; kykang@hknu.ac.kr(*corresponding author) \\ ${ }^{2}$ Gachon University, Department of Food Science and Biotechnology, College of BioNano Technology, Seongnam 461-701, \\ Republic of Korea \\ ${ }^{3}$ Chung-Ang University, Department of Food and Nutrition, College of Biotechnology and Natural Resource, Anseong, \\ Gyeonggi 17546, Republic of Korea; amdadbge@gmail.com \\ ${ }^{4}$ Hankyong National University, Institute of Genetic Engineering, Anseong, 17579, South Korea \\ ${ }^{a, b}$ These authors contributed equally to the work
}

\begin{abstract}
Sweet proteins are the natural alternative to the artificial sweeteners as well as flavor enhancers. Among other sweet protein, thaumatin protein was isolated from Thaumatococcus daniellii Benth plant fruit. In this study, pinII Ti plasmid vector was constructed with thaumatin gene, where thaumatin was placed under the control of the duel cauliflower mosaic virus $35 \mathrm{~S}$ promoter into rice (Oryza sativa L. var. japonica cv. 'Donginbyeo') by Agrobacterium-mediated transformation to generate transgenic plants. Thirteen plant lines were regenerated and the transgenic rice lines were confirmed by different molecular analysis. The genomic PCR result revealed that all of the plant lines were transgenic. The single copy and intergenic plant lines were selected by Taqman PCR analysis and FST analysis, respectively. Expression of thaumatin gene in transgenic rice resulted in the accumulation of thaumatin protein in the leave. Thaumatin protein was also accumulated in leave of T1 generation. Sensory analysis result suggested that the thaumatin protein expressing transgenic lines exerted sweet tasting activity. These results demonstrated that thaumatin was expressed in transgenic rice plants.
\end{abstract}

Keywords: Agrobacterium tumefaciens; Oryza sativa L; protein expression; taqman PCR; thaumatin

\section{Introduction}

In daily life, sugar is the popular sweetener which is used to prepare different types of foods or beverages. But over intake of such high caloric food product can create various complexities like dental caries, diabetic, obesity, etc. Patients with these types of diseases were using low caloric artificial sweeteners. The example of low caloric artificial sweeteners is acesulfame $\mathrm{K}$, cyclamate, aspartame and saccharin. Later, it was found that these low caloric artificial sweeteners created some other complexities, for example, bladder cancer, brain tumors, heart failure, psychological problems, mental disorders. Hence, there was an extreme necessity of alternative safe and healthy sweetener which could be able to exert sweetness property (Faus, 2000; Kant, 2005). Sweet proteins have traditional use and have been used to alter flavor or taste by suppressing the original taste of food and beverages. Recently, these proteins have been used as flavor enhancers and sweetening agents 
in the food processing industry. The sweet tasting proteins can exert their activities at very low concentrations and because of this property, they could be consumed by patients with tooth decay and diabetes. After the commercialization of thaumatin, there has been an accretive interest in these sweet proteins (Witty and Higginbotham, 1994; Sun et al., 2006). Thaumatococcus danielliii a West African rain forest shrub. The fruit obtained from $T$. daniellii plant has been used by native people to sweeten tea, palm wine and bread. The fruits were used by the West African people as sweeteners and flavor enhancers in food products (Etheridge, 1994). The active ingredient of the fruit is thaumatin (Van der Wel and Loeve, 1972; Witty and Higginbotham, 1994; Gibbs et al., 1996; Akter et al., 2016). It does not cause tooth decay. Moreover, it is safe to use by diabetic patients. At least eighteen investigations were executed from 1975 to 1985 and results pointed out no safety concerns (Higginbottom, 1985). The use of this sweet protein has many advantages. However, the commercial availability of thaumatin is very less as the natural source of this protein is $T$. daniellii plant which is not easy to grow outside of its natural atmosphere. On the basis of public's increasing demand for the particular product, extraction of thaumatin protein from the $T$. daniellii fruit may not be able to keep up with demand. Hence, as an alternative to the production of thaumatin from its native source, efforts have been made to produce recombinant thaumatin in foreign host (Daniell et al., 2000; Szwacka et al., 2002; Masuda et al., 2004). For easy accessibility, thaumatin proteins have been cloned into plants or microorganisms to express recombinant sweet protein. For the expression of thaumatin sweet protein in microbes, it was transformed into bacteria Bacillus subtilis, Escherichia coli, Streptomyces lividans; yeast Pichia pastoris, Saccharomyces cerevisiae, fungus Aspergillus oryzae, Aspergillus nigervar. awamori, Aspergillus awamori, Penicillium roquefortii (Baneyx, 1999; Daniell et al., 2000; Edens et al., 1982; Edens et al., 1984; ; Illingworth et al., 1988; Illingworth et al., 1989; Hahm and Batt, 1990; Weickmann et al., 1994; Faus et al., 1996; Makrides, 1996; Faus et al., 1997; Faus et al., 1998; Hannig et al., 1998; Moralejo et al., 1999; Masuda et al., 2004). Thaumatin was also expressed into plant systems like, tomato, potato, pear, cucumber, strawberry (Witty, 1990; Lebedev et al., 2002; Szwacka et al., 2002; Bartoszewski et al., 2003; Schestibratov and Dolgov, 2005). Until now, there is no report about the expression of thaumatin in rice.

The development of genetic transformation technology for plants has enabled the expression of various foreign genes in plants. Plants can be employed as bio-factories to produce valuable recombinant proteins, such as vaccines, mammalian hormones, antibodies, food additives and biopharmaceuticals (Hood and Jilka, 1999; Yoshida and Shinmyo, 2000; Daniell et al., 2001; Hood et al., 2002; Streatfield and Howard, 2003; Horn et al., 2004). In present study, we attempted to express the sweet protein, thaumatin, in rice (Oryza sativa L.). Rice is the very important crop plant because it is the staple food which feeds almost $50 \%$ of the world's population. Moreover, rice is widely grown all over the world. Expression of recombinant thaumatin in transgenic rice could provide an alternative expression system of this protein. Recombinant thaumatin was expressed in transgenic rice and displayed sweet tasting activity. In our sense, this is the first effort of expressing of thaumatin in transgenic rice.

\section{Materials and Methods}

\section{Bacterial strains and plant materials}

In this study, the bacterial strains of Escherichia coli DH5 $\alpha$ and Agrobacterium tumefaciens EH105 were taken from Plant Biotechnology Laboratory, Horticulture Life Science Department, Hankyong National University, Republic of Korea. E. coli DH5 $\alpha$ was used for cloning and A. tumefaciens EH105 was used for plant transformation. Rice cultivar (Oryza sativa L. var. japonica cv. 'Dongjinbyeo') seeds were collected from National Agrobiodiversity Center (National Agrobiodiversity Center, RDA, Suwon, Republic of Korea). Moreover, all chemical reagents used in this study were commercial products of the highest grade available. 


\section{Synthesize of thaumatin gene and vector construction}

The gene sequences of the thaumatin (GenBank Accession No: M21211.1), which harbor Flag-tag at the 3 '-terminus was synthesized by Bioneer. The synthetic thaumatin gene was cloned into pGEM $B_{1}$ vector including restriction sites 'XhoI and BamHI' (https://www.bioneer.co.kr/index.php/; Bioneer, Daejeon, Republic of Korea).

Synthesized thaumatin gene was digested from $\mathrm{PGEM} \mathrm{B}_{1}$ vector with 'XhoI and BamHI' and inserted into digested pinII Ti-plasmid vector. Thaumatin gene was driven by duel cauliflower mosaic virus $35 \mathrm{~S}$ promoter (2x CaMV 35S) where terminator was protease inhibitor II (pinII-T). BAR, Basta resistance gene was used as selectable marker gene. The constructed vector was transformed into $E$. coli $\mathrm{DH} 5 \alpha$ strain and named as pinII-thaumatin vector. T-DNA of pinII-thaumatin vector is shown in Figure 1. Transfection quality vector DNA was extracted from E. coli DH5 $\alpha$ and confirmed bacterial colony with Wizard ${ }^{\circ}$ Plus SV Minipreps DNA Purification System Protocol-Promega (Promega, USA) according to the manufacturer's instructions. Shortly, E. coli DH5 a was cultured in luria-bertani (LB) broth medium for $16 \mathrm{~h}$ at $37^{\circ} \mathrm{C}$ and the bacterial cells were collected by centrifugation. Cells were re-suspended into cell resuspension solution where alkaline protease solution and neutralization solution were added followed by centrifugation. After washing, the plasmid DNA was eluted by elution buffer and stored at $-20^{\circ} \mathrm{C}$ for further analysis.

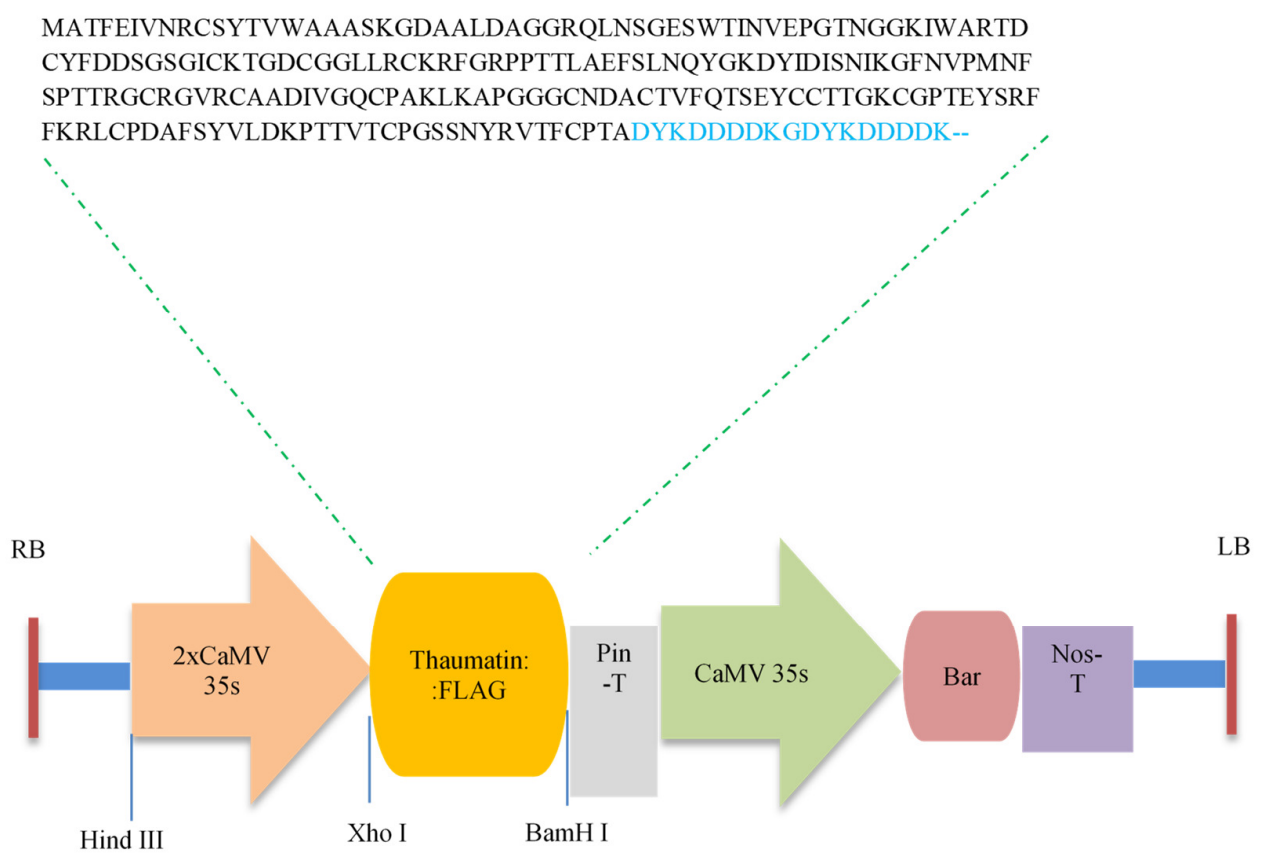

Figure 1. T-DNA region of pinII-thaumatin. Thaumatin, thaumatin gene; FLAG, Flag-tag epitope; RB, right border; LB, left border; Nos-T, nopaline synthase terminator; Pin-T, pinII terminator; 2xCaMV 35S, Duel Cauliflower mosaic virus $35 \mathrm{~S}$ promoter; CaMV 35S, Cauliflower mosaic virus $35 S$ promoter; Bar, selectable marker gene, basta resistant gene.

Agrobacterium-mediated transformation and plant regeneration 
The prepared recombinant expression pinII-thaumatin vector was transformed into rice calli by EHA105 strain (A. tumefaciens). The infected calli were cultured on 2N6-acetosyringone medium plate (coculture medium) and subcultured on 2N6-carbenicillin and PPT medium plate (selection medium). 1/2 MS (Murashige-Skoog) plates were used to grow the plants. The MS plates were supplemented with PPT and PPT was used to screen for PPT-resistant plant lines. To be confirmed the presence of transgene in the rooted shoots, PCR amplification was performed for regenerated plants before transferring them to plastic pots. Insertion of the foreign gene in plant genome was confirmed by PCR amplification of BAR gene (primers are listed in Table 1).

Table 1. Primers list for PCR amplification, FST analysis and RT-PCR amplification

\begin{tabular}{|c|c|}
\hline Primer name & Sequence (Primer direction 5'-3') $^{\prime}$ \\
\hline For BAR gene & \\
\hline Fw1 & CGT CAA CCA CTA CAT CGA GA \\
\hline Rv1 & TTG CGC GCT ATA TTT TGT TTT \\
\hline For thaumatin gene & ATG GCT ACC TTC GAA ATC GT \\
\hline Fw2 & GGC AGT TGG ACA GAA GGT AA \\
\hline Rv2 & \\
\hline For FST analysis & ACA CTC TTT CCC TAC ACG ACG CTC \\
\hline Barcode adaptor Fw $(\mathrm{F} 1)$ & TGG AGT AGA CGA GAG TGT CGA AGC TTC \\
\hline D35sP Rv $(\mathrm{R} 1)$ & TCG TTC AAA CAT TTG GCA AT \\
\hline Nos T Fw $(\mathrm{F} 2)$ & \\
\hline Common adaptor Rv $(\mathrm{R} 2)$ & CTG GTG ACT GTG GTG GTT TG \\
\hline For RT-PCR & GCA CAT CTG ACG CCT CTA CA \\
\hline RT-Fw3 & GGC TGT TTT CCC TAG TAT CG \\
\hline RT-Rv3 & GTA CGT CCA CTG GCA TAC AG \\
\hline Actin RT-Fw &
\end{tabular}

\section{Plant growth conditions}

Wild type (non-transgenic) and transgenic plants were grown in a growth chamber with a photoperiod of $16 \mathrm{~h}$ light $/ 8 \mathrm{~h}$ dark, $23 / 16^{\circ} \mathrm{C}$ day/night temperature, $50 \%$ relative humidity $(\mathrm{RH})$ and light intensity of 500 $1 \mathrm{~mol} \mathrm{~m}-2 \mathrm{~s}-1$. The development and seed production of wild type and transgenic rice lines were grown in the greenhouse at $20-22{ }^{\circ} \mathrm{C}$ during the day and $19-21^{\circ} \mathrm{C}$ at night, $40-75 \% \mathrm{RH}$. The supplemental light was used when light intensity went below $300 \mathrm{lmol} \mathrm{m-2} \mathrm{s-1} \mathrm{during} \mathrm{600-2200} \mathrm{h.}$

\section{Screening of promoter activity by gus assay}

To check 2x CaMV $35 S$ promoter activity, pinII-Gus recombinant vector was constructed by inserting GUS gene into the 'XhoI and BamHI' site of pinII vector. The GUS gene was controlled by a 2x CaMV 35S promoter which is used to construct pinII-thaumatin recombinant vector. The T-DNA of pinII-Gus vector is shown in Figure 2. The pinII-Gus vector was transformed into rice calli by Agrobacterium-mediated transformation. The infected calli were cultured on 1/2 MS plates. For the GUS assay analysis, both pinII-Gus vector inserted calli and untransformed calli (wild type) were used. The samples from the putative calli were incubated at $37^{\circ} \mathrm{C}$ for overnight in a gus solution (consisting of $50 \mathrm{mM} \mathrm{NaPO}_{4}(\mathrm{pH} 7.0), 10 \mathrm{mM} \mathrm{EDTA}^{\circ} 0.1 \%$ $(\mathrm{v} / \mathrm{v})$ triton X-100, 0.84 g/L K-Ferrocyanide, $0.66 \mathrm{~g} / \mathrm{L} \mathrm{K}$-Ferricyanide, $0.1 \mathrm{~g} / \mathrm{L}$ K-chloramphenicol and $1.0 \mathrm{~g} / \mathrm{L}$ $\mathrm{X}$-glucuronide). After incubation time, the solution was removed and calli were washed by $75 \%$ ethanol. For promoter activity checking, visual color was observed. 


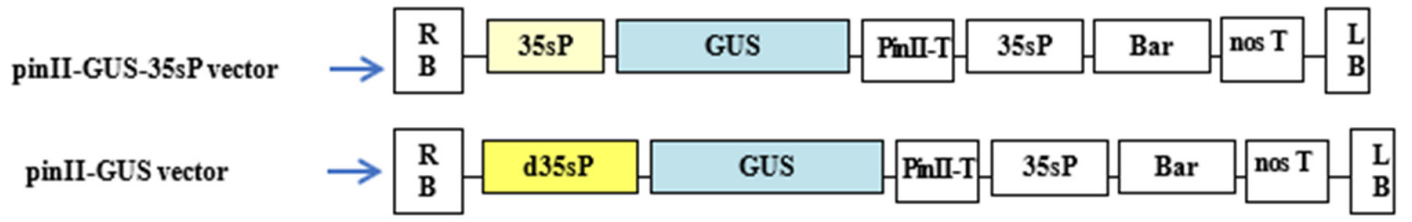

Figure 2. T-DNA region of pinII-GUS. GUS, GUS gene; RB, right border; LB, left border; nos-T, nopaline synthase terminator; PinII-T, pinII terminator; d35sP, Duel Cauliflower mosaic virus $35 \mathrm{~S}$ (2xCaMV 35S) promoter; 35sP, Cauliflower mosaic virus 35S (CaMV 35S) promoter; Bar, selectable marker gene, basta resistant gene; pinII-GUS-35sP vector contains CaMV 35 S promoter (35sP); pinIIGUS vector contains 2 XCaMV 35 S promoter (d35sP)

\section{Molecular analysis}

Genomic DNA isolation

For the isolation of genomic DNA, CTAB method was used. Briefly, samples were grinded until juice came out from the tissue. Then the juice was mixed with $1 \mathrm{~mL}$ CTAB extraction buffer (consisting of $2 \%$ CTAB (hexadecyl trimethyl-ammonium bromide), $1.4 \mathrm{M} \mathrm{NaCl}, 20 \mathrm{mM}$ EDTA and $100 \mathrm{mM}$ Tris- $\mathrm{HCl}, \mathrm{pH}$ 8.0). Afterwards, it was incubated for $30 \mathrm{~min}$ at $65^{\circ} \mathrm{C}$ water bath. $30 \mathrm{~min}$ later, the samples were centrifuged at $25^{\circ} \mathrm{C}$ at $12,000 \mathrm{rpm}$ for $15 \mathrm{~min}$. Aqueous phase was collected and transferred into new $1.5 \mathrm{~mL}$ tube and equal volume of chloroform:isoamyl was added. After centrifugation, the aqueous phase was collected in a new $1.5 \mathrm{~mL}$ centrifuge tube and isopropanol was added. The samples were incubated at $4{ }^{\circ} \mathrm{C}$ for an hour and DNA was pelleted after centrifugation for $15 \mathrm{~min} .70 \%$ ethanol was used to wash the pelleted DNA and the washed DNA was air dried. The dried DNA was suspended in sterile water supplemented with $10 \mathrm{mg} / \mathrm{mL} \mathrm{RNase}$ and stored at $-20^{\circ} \mathrm{C}$ for further use. The relative purity and concentration of extracted DNA was estimated by Nano-Drop-1000 (NanoDrop Technologies, Inc. USA).

\section{Polymerase chain reaction (PCR) analysis}

The RNase treated genomic DNA samples of wild type (WT) and pinII-thaumatin T0 plant lines were used for PCR amplification. Reactions have a final volume of twenty $\mu \mathrm{L}$ consisting of $10 \mathrm{pmol}$ forward primer, 10 pmol reverse primer, 10x PCR buffer, dNTP, Taq polymerase, sterile $\mathrm{H}_{2} \mathrm{O}$ and DNA template. T0 transgenic plant lines were confirmed by amplifying BAR gene (selectable marker gene). For BAR gene amplification conditions were: denaturation at $95^{\circ} \mathrm{C}$ for $5 \mathrm{~min}$, followed by 35 cycles of amplification $\left(94^{\circ} \mathrm{C}\right.$ for $1 \mathrm{~min}, 55^{\circ} \mathrm{C}$ for $1 \mathrm{~min}, 72^{\circ} \mathrm{C}$ for $2 \mathrm{~min}$ ), $72^{\circ} \mathrm{C}$ for $7 \mathrm{~min}$ and holding at $4^{\circ} \mathrm{C}$. The presence of the thaumatin gene in transgenic lines was confirmed by PCR amplification using thaumatin gene specific primers. Amplification conditions were: denaturation at $95^{\circ} \mathrm{C}$ for $5 \mathrm{~min}$, followed by 35 cycles of amplification $\left(94^{\circ} \mathrm{C}\right.$ for $1 \mathrm{~min}, 56^{\circ} \mathrm{C}$ for $1 \mathrm{~min}, 72^{\circ} \mathrm{C}$ for $2 \mathrm{~min}$ ), $72{ }^{\circ} \mathrm{C}$ for $7 \mathrm{~min}$ and holding at $4{ }^{\circ} \mathrm{C}$ (primers are listed in Table $1)$.

\section{Taqman real-time quantitative PCR (qPCR)}

For TaqMan real-time quantitative PCR analysis, LightCycler ${ }^{\circ} 480$ Probes Master kit (Roche) was used. TaqMan real-time quantitative PCR was carried out with a LightCycler 480 machine. For this analysis, the reactions have a final volume of ten $\mu \mathrm{L}$. It is consisting of following reagents: forward primer $(0.5 \mu \mathrm{M})$, reverse primer $(0.5 \mu \mathrm{M})$, LightCycler 480 Probes Master $(1 \times)$, TaqMan probes $(0.2 \mu \mathrm{M})$ and DNA template $(2.5 \mu \mathrm{L})$ and the amplification conditions were: denaturation at $95^{\circ} \mathrm{C}(10 \mathrm{~min})$, followed by 50 cycles of amplification $95^{\circ} \mathrm{C}(10 \mathrm{~s}), 56^{\circ} \mathrm{C}(30 \mathrm{~s})$ and cooling at $40^{\circ} \mathrm{C}(10 \mathrm{~s})$. Genomic DNA samples were tested using qPCR for both 
$5^{\prime}$ and $3^{\prime}$ regions of the ribosomal RNA gene for selection of single copy and the method was performed according to Wang et al., 2015.

\section{Flanking sequence tags (FSTs) analysis}

Genomic DNA was extracted from all of T0 transgenic plants and Taqman PCR analysis was performed to select single copy in the transgenic lines. Later, those single copied plants genomic DNA was used for inverse PCR (IPCR) (for FSTs analysis). Using the FSTs, the estimated position of genome, where T-DNA was inserted was confirmed after matching through NCBI blast program. IPCR is a method that relies on the results of digestion of the genome near the inserted T-DNA by a specific restriction enzyme and in this study, Ape $K I$ restriction enzyme was used. The FSTs reaction was performed for both left border (LB) and right border $(\mathrm{RB})$ of the T-DNA to enhance the recovery efficiency of FSTs.

In a new micro-centrifuge tube, $10 \mu \mathrm{L}$ of plant genomic DNA was taken and Ape $K I$ restriction enzyme was used to digest. For digestion of genomic DNA, the final volume was $20 \mu \mathrm{L}$ of a mixture consisting of sterile water, NEB buffer, working adaptor and Ape $K I$ in proportion. The samples were incubated at $75^{\circ} \mathrm{C}$ for $3 \mathrm{~h}$ and then kept on ice. The Ape $K I$ adapter was then ligated to the digested genomic DNA by mixing $20 \mu \mathrm{L}$ of each digested DNA with $50 \mu \mathrm{L}$ of a mixture containing sterile $\mathrm{H}_{2} \mathrm{O}, 10 \mathrm{X} \mathrm{T}_{4} \mathrm{DNA}$ ligase buffer and $\mathrm{T}_{4} \mathrm{DNA}$ ligase. The samples were then incubated at $22^{\circ} \mathrm{C}$ for $2 \mathrm{~h}$, after which the $\mathrm{T}_{4} \mathrm{DNA}$ ligase was inactivated by incubating the samples at $65^{\circ} \mathrm{C}$ and this solution was kept at $4^{\circ} \mathrm{C}$ until further experiment. Five $\mu \mathrm{L}$ of adapterligated genomic DNA was transferred to a new tube, followed by addition of $20 \mu \mathrm{L}$ of a mixture containing autoclaved $\mathrm{H}_{2} \mathrm{O}$, Taq DNA polymerase, 10X PCR buffer, dNTPs, forward primer and reverse primer. To amplify the regions flanking the $\mathrm{LB}$ of the T-DNA insert, $\mathrm{F} 1$ and $\mathrm{R} 1$ primers were used and amplification condition for 36 cycles were: consisting of 1 min at $94^{\circ} \mathrm{C}, 2$ min at $58^{\circ} \mathrm{C}$, and 2 min at $72^{\circ} \mathrm{C}$. For amplification of the regions flanking the $\mathrm{RB}$ of the T-DNA insert, the $\mathrm{F} 2$ and $\mathrm{R} 2$ primers were employed and amplification condition for 36 cycles were: consisting of $1 \mathrm{~min}$ at $94^{\circ} \mathrm{C}, 2 \mathrm{~min}$ at $55^{\circ} \mathrm{C}$, and $2 \mathrm{~min}$ at $72^{\circ} \mathrm{C}$ (primers are listed in Table 1).

Total RNA preparation and reverse transcriptase polymerase chain reaction (RT-PCR) analysis

RNA sample was isolated from both WT (untransformed) and transgenic plant leave. The leave was grinded to fine powder using liquid- $\mathrm{N}_{2}$ and FavorPrepTM Plant Total RNA Mini Kit (FAVORGEN, Republic of Korea) was used to isolate total RNA according to the manufacturer's instructions. In brief, the grinded fine powder was suspended in lysis buffer. Then the suspension was incubated at room temperature for $5 \mathrm{~min}$ and centrifuged at $18000 \mathrm{xg}$ for $1 \mathrm{~min}$. The supernatant was collected and DNase I was added to avoid genomic DNA contamination. After washing and the RNA sample was eluted and stored at $-70^{\circ} \mathrm{C}$ for further analysis. The cDNA was synthesized from total RNA using Inclone TM One-step RT-PCR kit [Hot-Taq] Inclone Biotech, Republic of Korea) according to the manufacturer's instructions (primers are listed in Table 1).

Extraction and stable expression analysis of thaumatin protein by western blot

The protein sample was extracted from both WT (untransformed) and transgenic plant leave. The leave was grinded with the use of extraction buffer [ consisting of $2.0 \mathrm{M} \mathrm{KPO}_{4}(\mathrm{pH} 7.8), 0.5 \mathrm{M}$ ethylenediaminetetraacetic acid (EDTA), Triton X-100, 1.0 M dithiothreitol (DTT), 80\% glycerol and $\mathrm{H}_{2} \mathrm{O}$ ]. The liquid was collected and centrifuged at $4{ }^{\circ} \mathrm{C}$ at $15,000 \mathrm{rpm}$ for $20 \mathrm{~min}$. After centrifugation, the supernatant was collected and used for further analysis. Protein concentration was determined according to Bradford (1976) method using Bio-Rad protein stain with bovine serum albumin as a standard.

The protein samples were prepared from the wild type (untransformed) as well as transgenic plant lines and loaded on 12.0\% (w/v) SDS polyacrylamide gels (Laemmli, 1970) and electro-blotted onto PVDF membrane (Bio-Rad). The membrane was then incubated in blocking solution $[5 \%(\mathrm{w} / \mathrm{v})$ non-fat dried milk in TBS-T buffer (20 mM Tris-Cl, pH 7.5, $500 \mathrm{mM} \mathrm{NaCl}$, and 0.05\% Tween 20). Monoclonal ANTI-FLAG ${ }^{\circ}$ 
M2-Peroxidase (HRP) antibody produced in mouse (sigma, catalogue number A8592) was used as a primary antibody (1:1000, v/v) and Goat Anti-Rabbit IgG H\&L (HRP) (abcam, catalogue number ab6721) was used as the secondary antibody $(1: 4000, \mathrm{v} / \mathrm{v})$. The blots were then developed using the enhanced chemiluminescence (ECL) developing system (ATTO Corporation, Japan).

\section{Sensory analysis}

Sweetness assay (blind test) of transgenic plants developed by thaumatin gene was performed according to Witty and Harvey (1990) and Bartoszewski et al. (2003) with modifications. Five participants were asked to taste leaves samples and describe the taste. Five volunteer participants were consisting of both males and females (ages 22 to 60 years). None of the participants exhibited any irregularities in their sense of taste. All participants were randomly selected and given full disclosure of the aim of the study and their roles. For this assay, leave of both wild type (untransformed) and transgenic lines were used. Fresh leave samples were collected from green house and washed with water. Grinded to fine powder by liquid nitrogen, freeze dried the sample. Afterwards, sample was dissolved in water and participants were asked to taste samples and describe the taste. Three transgenic samples were given to participants (prepared from the transgenic lines T-10, T-11, $\mathrm{T}-12$ and the untransformed control). The subject's mouth was rinsed three times by drinking water after each test. The order of presentation of the samples was randomized and the blind taste test was repeated three times.

\section{Results and Discussion}

\section{Screening of promoter activity by gus assay}

Promoter activity is very important for gene expression. In present study $2 \mathrm{x}$ CaMV $35 \mathrm{~S}$ promoter was used to overexpress thaumatin gene in rice plants. To confirm the promoter activity, pinII-GUS vector was constructed, where GUS gene was driven by $2 \mathrm{x}$ CaMV 35 s promoter. For GUS assay, wild type calli (untransformed) and pinII-GUS vector inserted calli were taken and placed into gus solution. After overnight incubation in the gus solution, the positive calli turned to green color. From the GUS assay result, it was found that, the wild type did not turn to green. But the GUS gene inserted calli turned into green color (positive result) (Figure 3). This result indicated that the $2 \mathrm{x}$ CaMV 35 S promoter was working properly and perfectly.

\section{Generation and characterization of pinii-thaumatin transgenic plants}

PinII-thaumatin recombinant vector was constructed with thaumatin gene and transformed into rice calli by Agrobacterium-mediated transformation (Figure 4), where thaumatin gene expression was driven by 2x CaMV $35 S$ promoter (Figure 1). Transgenic plants containing pinII-thaumatin were generated using PPT. After infection of rice calli by EHA105, thirteen PPT resistant calli were regenerated (100\%).

To confirm gene insertion into rice genome, genomic DNA was isolated from thirteen T0 lines and PCR amplification was performed for transgene and specific gene insertion. For the confirmation of transgenic plants, PCR analysis was performed with thirteen T0 plants and results showed positive amplification of BAR gene (Figure 5A). When the PCR analysis was performed for thaumatin gene, the result revealed that all the thirteen lines were positive for thaumatin gene insertion (Figure 5B). Then all of those $\mathrm{T} 0$ transgenic lines were transferred into soil pot and grown for further experiments. 


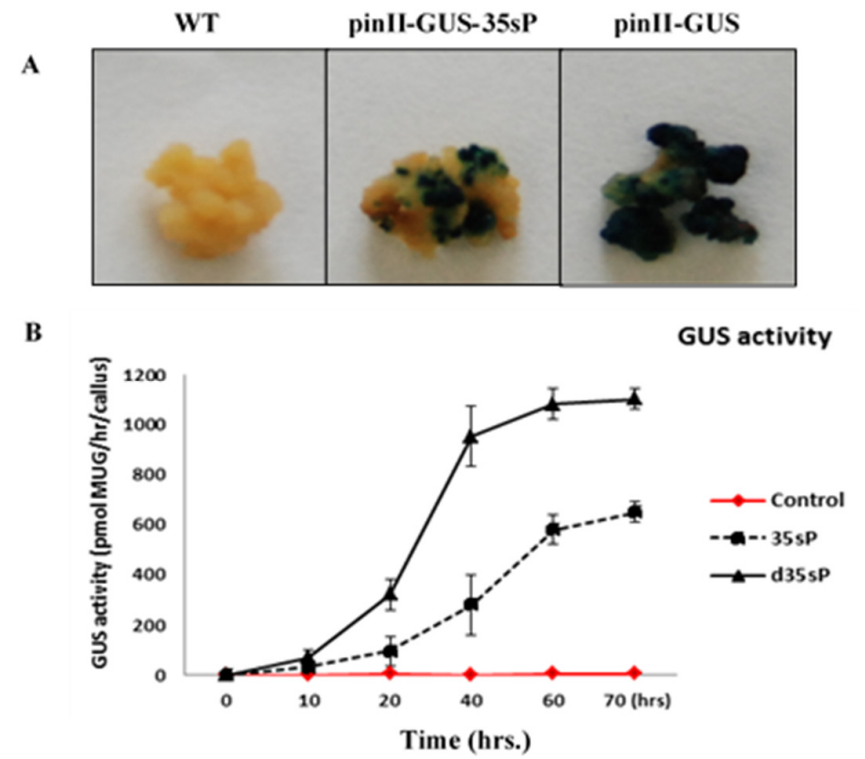

Figure 3. Analysis of GUS activity (promoter activity check by GUS assay) in callus transformed with Agrobacterium containing GUS reporter gene

The wild type (WT) (untransformed) callus, pinII-GUS vector containing 2XCaMV 35S (d35sP) promoter and pinII-GUS-35sP vector containing CaMV 35S (35sP) promoter, respectively, culli were placed into gus solution. After incubation, positive result showed green color for both pinII-GUS and pinII-GUS-35sP vectors, respectively, while pinII-GUS (containing 2XCaMV $35 \mathrm{~S}$ promoter) showed significantly more activity than pinII-GUS-35sP (containing CaMV $35 \mathrm{~S}$ promoter). Hence, $2 \mathrm{XCaMV} 35 \mathrm{~S}$ promoter was selected during pinII-thaumatin vector construction. Moreover, WT callus did not turn into green color. A; Pictures of representative callus from histochemical analysis of GUS assay. B; Time course changes of GUS activity in transgenic callus suspension culture. Data presented are means \pm SD of three independent replicated experiments.

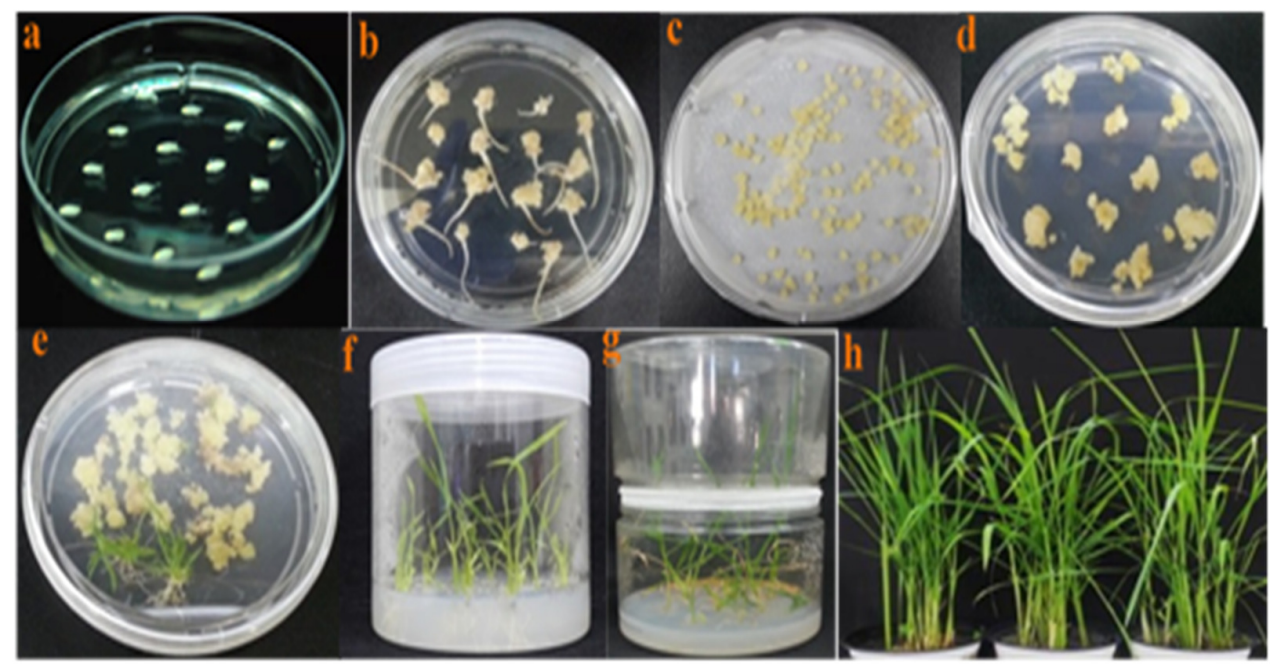

Figure 4. Agrobacterium-mediated transformation and development of transgenic rice plants with thaumatin. a-b, seed sowing and callus formation; c, callus infection; $d$, callus formation after 
infection; e, multi-shoot differentiation; f-g, regenerated plants in rooting medium; h, acclimation in soil

(A)

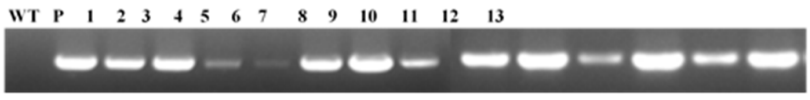

(B)

\section{प-}

Figure 5. Polymerase chain reaction for pinII-thaumatin

(A) Transgenic plants confirmation by BAR gene insertion PCR. WT, wild type (untransformed); P, pinII-thaumatin plasmid; $1 \sim 13, \mathrm{~T}-01 \sim \mathrm{T}-13$, regenerated plant lines with pinII-thaumatin. (B) Thaumatin gene specific PCR amplification. WT, wild type (untransformed); P, pinII-thaumatin plasmid; $1 \sim 13, \mathrm{~T}-01 \sim \mathrm{T}-13$, regenerated plant lines with pinII-thaumatin.

\section{Selection of single copy transgenic lines by Taqman PCR}

The genomic DNA was isolated from the fresh leave of each of transgenic plant lines. Then the genomic DNA sample was used and the transgene copy numbers in the transgenic rice genomes were analyzed by Taqman PCR where actin gene and NOS gene probes were used. The copy number values of ten transgenic lines showed between 0.5 and 1.0, thus indicating single copy of transgene. From the analysis result, it was found that out of thirteen T0 plants, seven lines (T-02, T -06, T-07, T -09, T-10, T-11 and T-12) contained single copy of gene. It indicated that single copy ratio of the thaumatin gene in the rice genome was $53.8 \%$. The remaining plant lines contained three or more copies of the gene (Table 2, Figure 6).

Table 2. Copy number frequency of pinII-thaumatin in T0 trasnformants

\begin{tabular}{|c|c|c|c|c|}
\hline \multirow{2}{*}{ Lines } & \multicolumn{3}{|c|}{ TaqMan copy assay } & \multirow{2}{*}{$\begin{array}{c}\text { Single copy } \\
(\%)\end{array}$} \\
\cline { 2 - 4 } & 1 copy & 2 copies & Multi copies & 53.8 \\
\hline 13 & 7 & 0 & 6 & 5 \\
\hline
\end{tabular}

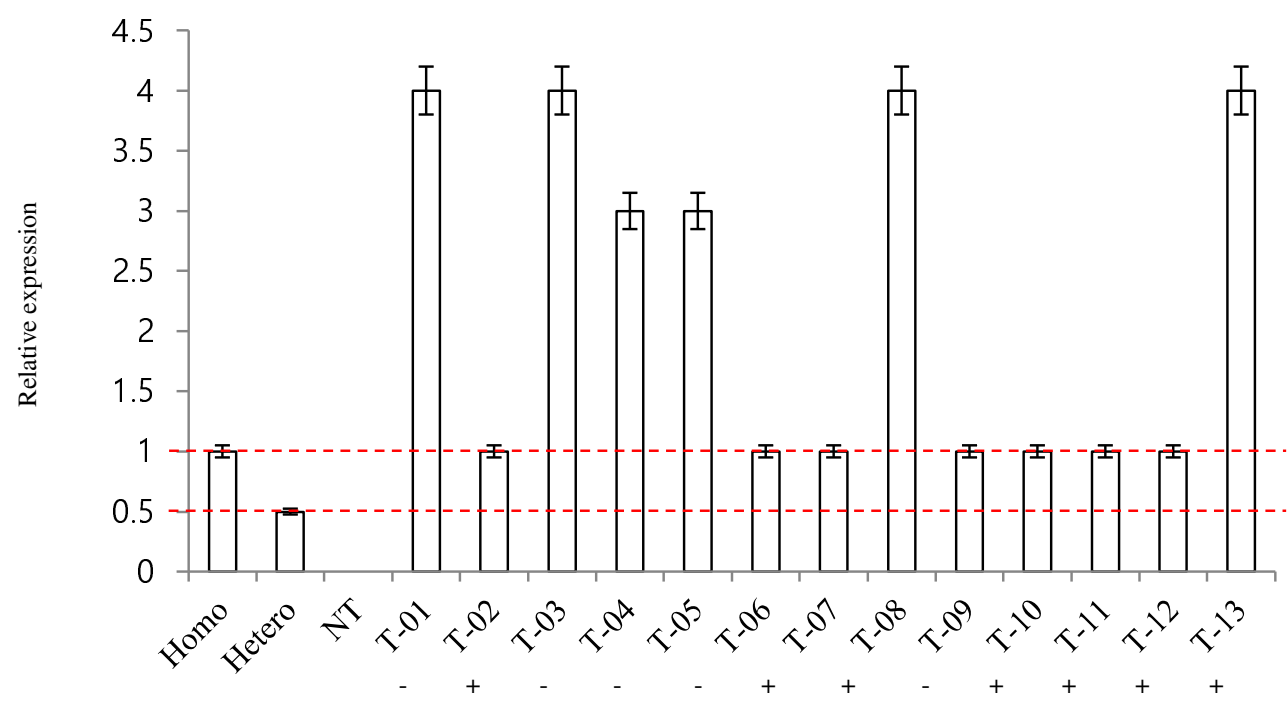


Figure 6. TaqMan PCR analysis of thaumatin gene for copy number assays using TaqMan probe for selecting single copy in T0 transgenic rice. Homo, T0 Homo; Hetero, T0 hetero; NT, negative control; + single copy, -, multicopy; T-01 T-13, T0 transgenic lines. Each level is generated from the DNA template of independent $\mathrm{T} 0$ transgenic lines

\section{Intergenic line selection using inverse PCR (IPCR)}

FSTs analysis was made based on Thole et al. (2009) by extraction and restriction digest of genomic DNA followed by ligation of an adapter to the genomic DNA. Afterwards, PCR amplification of the regions flanking the T-DNA insert(s) using primers specific to the adapter and the T-DNA. And then PCR product was sequenced and sequencing result was analyzed by NCBI blastn program to identify the position of T-DNA in rice genome. There were seven T0 transgenic plants subjected to IPCR analysis using specific primers for ApeKI adapter and T-DNA primers flanking the RB and LB sites. Based on the nucleotide sequences of the FSTs analysis through the NCBI blastn program, it allowed selection of three intergenic lines (42.9\%).

Result suggested that the T-DNA of T-10 fell between Os03g0844450 (exosome complex component MTR3) and Os03g0845000 (Putative pirin-like protein) in chromosome 3 (Chr03), between Os02g0668700 (GRAS (GAI-RGA-SCR) plant-specific transcription factor) and Os02g0669500 (Similar to H0211B05.7 protein) genes in $\mathrm{Chr} 02$ for $\mathrm{T}-11$, between Os03g0837900 (Streptomyces cyclase/dehydrase family protein) and Os03g0838500 (Peptidase S8, subtilisin-related domain containing protein) genes in Chr03 for T-12 line (Figure 7.).

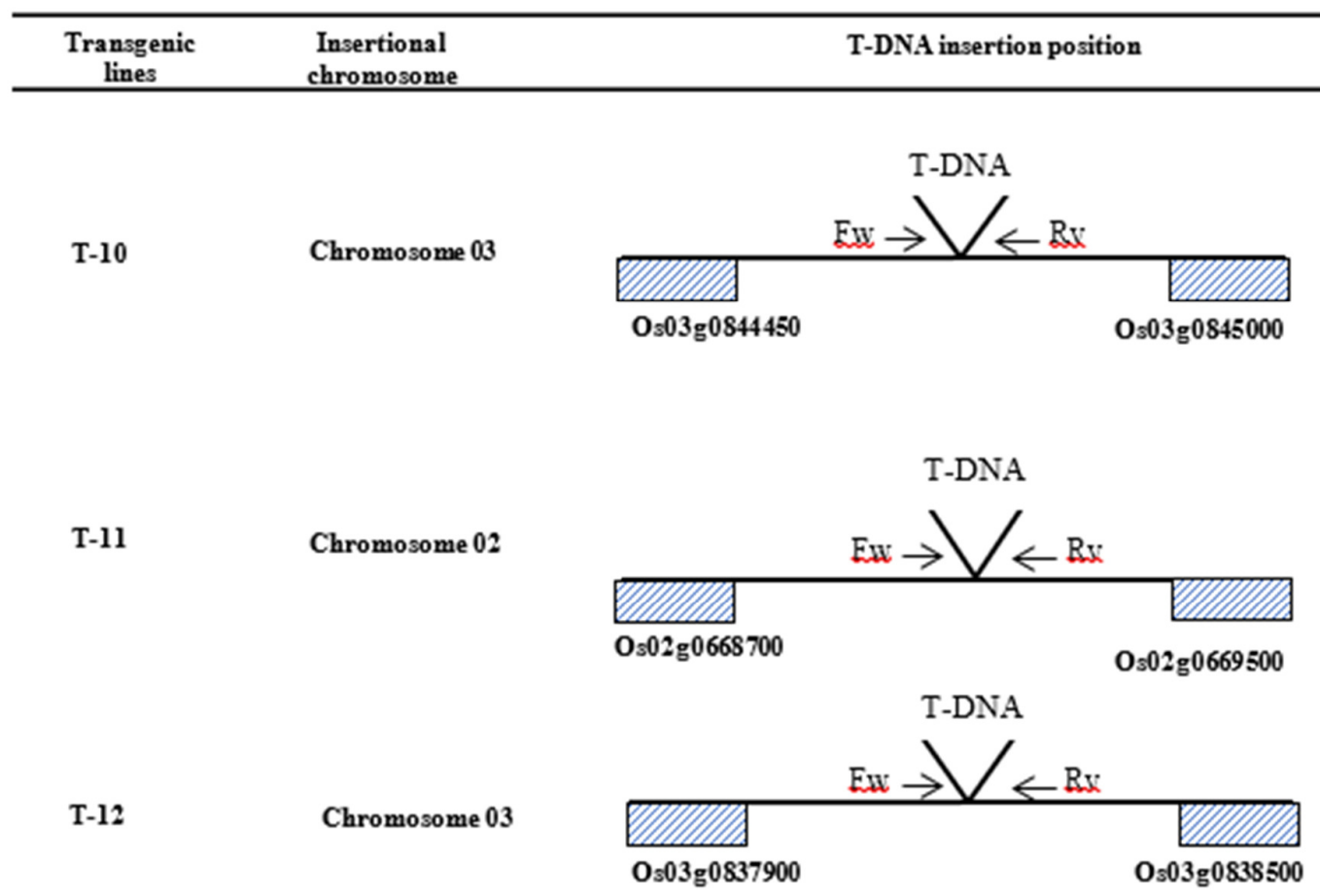

Figure 7. Identification of pinII-thaumatin insertion transgenic plants

The genomic structures of insertion alleles were determined by FST analysis in which genes (boxes) and T-DNA of pinII-thaumatin are shown, respectively. Os03g0844450, exosome complex component MTR3; Os03g0845000, Putative pirin-like protein; Os02g0668700, GRAS (GAI-RGA-SCR) plant-specific transcription factor; Os02g0669500, Similar to H0211B05.7 protein; Os03g0837900, Streptomyces cyclase/dehydrase family protein; Os03g0838500, Peptidase S8, subtilisin-related domain containing protein. 


\section{$R N A$ expression analysis by $R T-P C R$}

Three T0 transgenic plants (T-10, T-11 and T-12) were used in RNA expression analysis. Total RNA was extracted from leave of both WT (untransformed) and transgenic plants for thaumatin gene expression analysis. RT-PCR was performed to examine thaumatin mRNA expression levels in transgenic rice lines T-10, T-11 and T-12. Expression of thaumatin was confirmed in all these three transgenic lines. Such amplification was not observed in WT plants line (Figure 8). The RNA expression analysis result confirmed the presence of thaumatin gene in its transgenic lines, whereas no transcripts were detected in wild type.

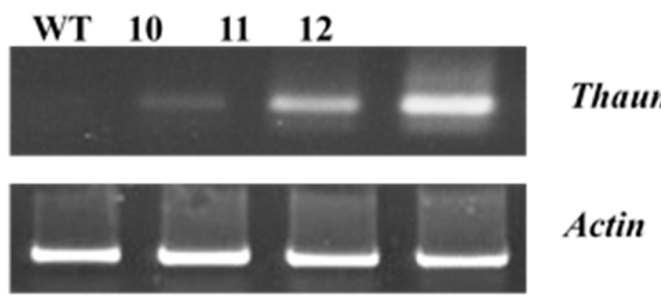

Figure 8. Expression analysis for thaumatin gene in transgenic lines

Gene expression analysis by RT-PCR. Total RNA was isolated from wild type and transgenic lines. $0.3 \mu \mathrm{g}$ of this RNA was amplified with gene specific primers. Rice actin gene was amplified as a loading control. WT, wild type (untransformed); 10, T-10; 11, T-11; 12, T-12 transgenic lines of pinII-thaumatin.

\section{Expression of thaumatin protein in transgenic plants}

To confirm the expression of thaumatin protein, total soluble protein was extracted from the leave of $\mathrm{T} 0$ transgenic rice lines (T-10, T-11 and T-12) and WT line and analyzed by western blot. Result showed that thaumatin protein was expressed in all $\mathrm{T}-10, \mathrm{~T}-11$ and $\mathrm{T}-12$ transgenic lines but there was no such protein expression in WT (untransformed) plant. The thaumatin protein expressing T0 lines were transferred to soil and grown in green house and T1 seeds were collected. T1 seeds were germinated in soil for analysis of the stability of transgene expression and inheritance. The presence and expression of the transgene in T1 seedlings of the transgenic lines were investigated by genomic polymerase chain reaction as well as western blot analysis (Figure 9). The thaumatin protein expression in the leave of the T1 generation was similar to that of the T0 progeny. These results confirmed that the thaumatin protein is expressed as well as inherited in transgenic rice plants as the generations advance.

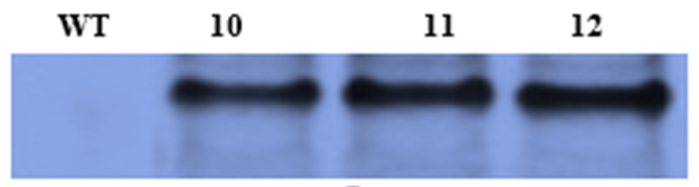

Figure 9. Stable expression analysis for thaumatin protein in transgenic lines by western blot Protein sample was isolated from wild type and transgenic lines. Monoclonal ANTI-FLAG ${ }^{\bullet}$ M2-Peroxidase (HRP) antibody produced in mouse (sigma) was used as primary antibody and Goat Anti-Rabbit IgG H\&L (HRP) (abcam) was as secondary antibody. Lane WT, wild type (untransformed); 10, T-10; 11, T-11; 12, T-12 transgenic lines of pinII-thaumatin.

\section{Sensory analysis}

The sweet tasting activity of recombinant thaumatin protein was assayed by sensory analysis using blind taste test of five participants. It was found that the transgenic lines developed with thaumatin had sweet tasting activity, while the wild type (untransformed) did not exert such activity. All five volunteer participants described the sweet tasting activity of leave samples from transgenic lines (developed by thaumatin) as strongly distinguishable from the wild type (untransformed) leave sample. These observations suggested that transgenic rice lines expressing thaumatin in its transgenic plant lines. 
Consumption of high caloric food made by sugar or refined sugar can cause numerous complexities such as obesity and related problems like, dental caries, sleep apnoea, type II diabetes and osteoarthritis. Other side effects such as, brain tumors, bladder cancer, higher probability of heart diseases, even mental disorders also can be caused. Therefore, there was an inquest necessity of low caloric and natural alternatives to sugar which can be safely used in foods, beverages and medicines. Thaumatin sweet protein could be a potential alternative as low caloric sugar (Price et al., 1970; Assadi-Porter et al., 2000; Kant, 2005; Akter et al., 2016). But the enough production of thaumatin protein from its natural source $(T$. daniellii) is impossible as it is difficult and expensive to grow the $T$. daniellii plants other than its environment. There are many report of expression of thaumatin in different foreign hosts such as E. coli, B. subtilis, S. lividans, P. pastoris, S. cerevisiae, A. oryzae, A. niger var. awamori, fungus $P$. roquefortii, tomato, potato, cucumber, pear and strawberry (Baneyx, 1999; Bartoszewski et al., 2003; Daniell et al., 2000; Edens et al., 1982; Edens et al., 1984; Faus et al., 1996; Faus et al., 1997; Faus et al., 1998; Hahm and Batt, 1990; Hannig et al., 1998; Illingworth et al., 1988; Illingworth et al., 1989; Lebedev et al., 2002; Makrides, 1996; Masuda et al., 2004; Moralejo et al., 1999; Schestibratov and Dolgov, 2005; Szwacka et al., 2002; Weickmann, Blair and Wilcox, 1994; Witty, 1990). Until now there is no report about the transformation of this valuable natural sweetener, thaumatin, into rice plant system. In this study, transgenic rice plants were used for stable expression of natural sweetener, thaumatin. In our knowledge, it is the first-time attempt of expression of thaumatin transgene in rice line. There are many reports showed that transgenic plants have been developed as recombinant protein expression systems. Plant expression systems have different benefits: there is lack of animal pathogens, possibility of large scale production, proteins expression in seeds provides a natural site for the long term storage and effective production costs (Daniell et al., 2001; Hood and Jilka, 1999; Hood et al., 2002; Horn et al., 2004; Howard and Hood, 2005; Lamphear et al., 2005; Streatfield, 2007; Streatfield and Howard, 2003; Sun et al., 2007; Yoshida and Shinmyo, 2000). The expression of transgenic proteins in eatable crops has the specific benefit to synthesis products that can be directly eaten (Streatfield and Howard, 2003).

The present study showed the genetically stable expression of thaumatin protein in transgenic rice plants. Furthermore, thaumatin in transgenic rice controlled by 2x CaMV $35 S$ promoter and the purpose of this study was to develop a new rice cultivar with thaumatin sweet protein. The expression of transgenes in plant lines is influenced by the T-DNA insertion site and the transgene copy number. It also cannot be ruled out that the insertion of transgene loci may cause stability problems to the plant itself, if disrupting certain parts of the genome (Colinas et al., 2008). Therefore, in contrast to other transgenic studies, we focused on a single copy and intergenic locations of transgenes, starting from $\mathrm{T} 0$ generation in order to ensure a stable expression. We can conclude our outcome depending on different experiments in T0 and T1 generations such as mRNA expression analysis of thaumatin in transgenic rice lines as well as western blot analysis where specific antibody was used and result confirmed the thaumatin was stably expressed in transgenic rice lines. Moreover, the sweetness property of transgenic plants was checked. According to the participants, transgenic lines exerted sweet tasting activity. In the present study, we have shown that rice plant expression system can be used for the expression of thaumatin protein. Hence, transgenic plants can be considered as an alternative production system to increase the availability of this sweet protein.

\section{Conclusions}

Low caloric, healthy and natural sweetener is essential for everyday life because ingestion of high calorie food can cause various diseases. Hence, if thaumatin protein could be expressed in crop plants, it might be an alternative source of low caloric sweetener. In this study, it is shown that the expression of thaumatin in transgenic lines by selecting single and intergenic lines from thaumatin transgenic rice lines. Moreover, the stable expression of thaumatin was observed as generation advances. The sweet taste assay proved the sweet 
tasting activity of transgenic lines. Finally, it could be concluded that the developed transgenic plants with thaumatin could be able to express thaumatin protein.

\section{Authors' Contributions}

All authors read and approved the final manuscript.

\section{Acknowledgements}

This research was supported by a grant from the Next-Generation BioGreen 21 Program (Project No. PJ01368902), Rural Development Administration, and by Basic Science Research Program through the National Research Foundation of Korea (NRF) funded by the Ministry of Education, Science and Technology (2017R1C1B5017833), Republic of Korea.

\section{Conflict of Interests}

The authors declare that there are no conflicts of interest related to this article.

\section{References}

Akter S, Huq MA, Jung YJ, Cho YG, Kang KK (2016). Application of sweet and taste modifying genes for development in plants: current status and prospects. Journal of Plant Biotechnology 43:397-404.

Assadi-Porter FM, Aceti D, Markley JL (2000). Sweetness determinant sites of brazzein, a small, heat-stable, sweet tasting protein. Archives of Biochemistry and Biophysics 376(2):259-265.

Baneyx F (1999). Recombinant protein expression in Escherichia coli. Current Opinion in Biotechnology 10:411-421.

Bartoszewski G, Niedziela A, Szwacka M, Niemirowicz-Szczytt K (2003). Modification of tomato taste in transgenic plants carrying a thaumatin gene from Thaumatococcus daniellii Benth. Plant Breeding 122:347-351.

Bradford MM (1976). A rapid and sensitive method for the quantitation of microgram quantities of protein utilizing the principle of protein-dye binding. Analytical Biochemistry 72:248-254.

Colinas J, Schmidler SC, Bohrer G, Iordanov B, Benfey PN (2008). Intergenic and genic sequence lengths have opposite relationships with respect to gene expression. PLoS One 3(11):e3670.

Daniell H, Streatfield SJ, Wycoff K (2001). Medical molecular farming: production of antibodies, biopharmaceuticals and edible vaccines in plants. Trends in Plant Science 6:219-226.

Daniell S, Mellits KH, Faus I, Connerton I (2000). Refolding the sweet-tasting protein thaumatin II from insoluble inclusion bodies synthesized in Escherichia coli. Food Chemistry 71:105-110.

Edens L, Bom L, Ledeboer AM, Maat J, Toonen MY, Visser C, Verrips CT (1984). Synthesis and processing of the plant protein thaumatin in yeast. Cell 37:629-633.

Edens L, Heslinga L, Klok R, Ledeboer AM, Maat J, Toonen MY, ... Verrips CT (1982). Cloning of cDNA encoding the sweet-tasting plant protein thaumatin and its expression in Escherichia coli. Gene 18:112.

Etheridge K (1994). The sales and marketing of Talin. In: Witty M, Higginbotham JD, eds. Thaumatin, Boca Raton: CRC Press 1994:47-59. 
Faus I (2000). Recent developments in the characterization and biotechnological production of sweet-tasting proteins. Applied Microbiology and Biotechnology 53:145-151.

Faus I, del Moral C, Adroer N, del Río JL, Patiño C, Sisniega H, ... Rubio V (1998). Secretion of the sweet tasting protein thaumatin by recombinant strains of Aspergillus niger var. awamori. Applied Microbiology and Biotechnology 49:393-398.

Faus I, Patiño C, del Río JL, del Moral C, Barroso HS, Bladé J, Rubio V (1997). Expression of a synthetic gene encoding the sweet-tasting protein thaumatin in the filamentous fungus Penicillium roquefortii. Biotechnology Letters 19:1185-1191.

Faus I, Patiño C, Río JL, del Moral C, Barroso HS, Rubio V (1996). Expression of a synthetic gene encoding the sweet-tasting protein thaumatin in Escherichia coli. Biochemical and Biophysical Research Communications 229(1):121-127.

Gibbs BF, Alli I, Mulligan C (1996). Sweet and taste-modifying proteins: a review. Nutrition Research 16:1619-1630.

Hahm YT, Batt CA (1990). Expression and secretion of thaumatin from Aspergillus oryzae. Agricultural and Biological Chemistry 54:2513-2520.

Hannig G, Makrides SC (1998). Strategies for optimizing heterologous protein expression in Escherichia coli. Trends in Biotechnology 16:54-60.

Higginbottom HJD (1985). Talin update. Food Flavorings, Ingredients, Processing \& Packaging. 1985, 7(Jan), 39.

Hood EE, Jilka JM (1999). Plant-based production of xenogenic proteins. Current Opinion in Biotechnology 10:382-386.

Hood EE, Woodard SL, Horn ME (2002). Monoclonal antibody manufacturing on transgenic plants- myths and realities. Current Opinion in Biotechnology 13:630-635.

Horn ME, Woodard SL, Howard JA (2004). Plant molecular farming: systems and products. Plant Cell Reports 22:711-720.

Howard JA, Hood E (2005). Bioindustrial and biopharmaceutical products produced in plants. Advances in Agronomy 85:91-124.

Illingworth C, Larson G, Hellekant G (1988). Secretion of the sweet-tasting plant protein thaumatin by Bacillus subtilis. Biotechnology Letters 10:587-592.

Illingworth C, Larson G, Hellekant G (1989). Secretion of the sweet-tasting plant protein thaumatin by Streptomyces lividans. Journal of Industrial Microbiology and Biotechnology 4:37-42.

Kant R (2005). Sweet proteins, potential replacement for artificial low-calorie sweeteners. Nutrition Journal 4:5.

Laemmli UK (1970). Cleavage of structural proteins during the assembly of the head of bacteriophage T4. Nature 227:680-685.

Lamphear BJ, Barker DK, Brooks CA, Delaney DE, Lane JR, Beifuss K, ... Howard JA (2005). Expression of the sweet protein brazzein in maize for production of a new commercial sweetener. Plant Biotechnology Journal 3:103-114.

Lebedev VG, Taran SA, Shmatchenko VV, Dolgov SV (2002). Pear transformation with the gene for super sweet protein thaumatin II. Acta Horticulturae 596:199-202.

Makrides SC (1996). Strategies for achieving high-level expression of genes in Escherichia coli. Microbiological Reviews 60:512-538.

Masuda M, Tamaki S, Kaneko R, Wada R, Fujita Y, Mehta A, Kitabatake N (2004). Cloning, expression, and characterization of recombinant sweet-protein thaumatin II using the methylotrophic yeast Pichia pastoris. Biotechnology and Bioengineering 85:761-769.

Moralejo FJ, Cardoza RE, Gutierrez S, Martin JF (1999). Thaumatin production in Aspergillus awamori by use of expression cassettes with strong fungal promoters and high gene dosage. Applied and Environmental Microbiology 65:1168-1174. 
Price JM, Biava CG, Oser BL, Vogin EE, Steinfield J, Ley HL (1970). Bladder tumors in rats fed cyclohexylamine or high doses of a mixture of cyclamate and saccharin. Science 167:1131-1132.

Schestibratov KA, Dolgov SV (2005). Transgenic strawberry plants expressing a thaumatin II gene demonstrate enhanced resistance to Botrytis cinerea. Scientia Horticulturae 106:177-189.

Streatfield SJ, Howard JA (2003). Plant-based vaccines. International Journal for Parasitology 33:479-493.

Streatfield SJ (2007). Approaches to achieve high-level heterologous protein production in plants. Plant Biotechnology Journal 5:2-15.

Sun HJ, Cui ML, Ma B, Ezura H (2006). Functional expression of the taste-modifying protein, miraculin, in transgenic lettuce. FEBS Letter 580:620-626.

Sun HJ, Kataoka H, Yano M, Ezura H (2007). Genetically stable expression of functional miraculin, a new type of alternative sweetener, in transgenic tomato plants. Plant Biotechnology Journal 5:768-777.

Szwacka M, Kryzymowska M, Osuch A, Kowalczyk ME, Malepszy S (2002). Variable properties of transgenic cucumber plants containing the thaumatin II gene from Thaumatococcus daniellii. Acta Physiologiae Plantarum 24:173-185.

Thole V, Alves SC, Worland B, Bevan MW, Vain P (2009). A protocol for efficiently retrieving and characterizing flanking sequence tags (FSTs) in Brachypodium distachyon T-DNA insertional mutants. Nature Protocols 4:650-661.

Van der Wel H, Loeve K (1972). Isolation and characterization of thaumatin I and II, the sweet-tasting proteins from Thaumatococcus danielliii Benth. European Journal of Biochemistry 31:221-225.

Wang X, Jiang D, Yang D (2015). Fast-tracking determination of homozygous transgenic lines and transgene stacking using a reliable quantitative real-time PCR assay. Biotechnology and Applied Biochemistry 175:996-1006.

Weickmann JL, Blair LC, Wilcox GL (1994). High level expression of thaumatin in Saccharomyces cerevisiae. In: Witty M and Higginbotham JD (ed.), Thaumatin. CRC Press, Boca Raton, FL, pp 151-169.

Witty M (1990). Preprothaumatin II is processed to biological activity in Solanum tuberosum. Biotechnology Letter 12:131-136.

Witty M, Higginbotham JD (1994). Thaumatin, CRC Press, Boca Raton, FL.

Witty M, Harvey WJ (1990). Sensory evaluation of transgenic Solanum tuberosum producing r-thaumatin II. New Zealand Journal of Crop and Horticultural Science 18:77-80.

Yoshida K, Shinmyo A (2000). Transgenic expression systems in plants, a natural bioreactor. Journal of Bioscience and Bioengineering 90:353-362. 
OPEN ACCESS

(c)

The journal offers free, immediate, and unrestricted access to peer-reviewed research and scholarly work. Users are allowed to read, download, copy, distribute, print, search, or link to the full texts of the articles, or use them for any other lawful purpose, without asking prior permission from the publisher or the author.

License - Articles published in Notulae Botanicae Horti Agrobotanici Cluj-Napoca are Open-Access, distributed under the terms and conditions of the Creative Commons Attribution (CC BY 4.0) License. (C) Articles by the authors; UASVM, Cluj-Napoca, Romania. The journal allows the author(s) to hold the copyright/to retain publishing rights without restriction. 